\title{
ФОРМУВАННЯ ГАРМОНИЙНО РОЗВИНУТОЇ ОСОБИСТОСТІ, ЗДАТНОЇ ДО ЩАСЛИВОГО ЖИТТЯ ЧЕРЕЗ САМОРАЛІЗАЦЮЮ В СПОРТІ
}

\author{
Клімакова С. М. \\ старший викладач кафедри циклічних видів спорту, \\ Харківський національний педагогічний університет імені Г. С. Сковороди, \\ м. Харків, Україна
}

Формування гармонійно розвинутої особистості спортсмена є актуальним для практичної роботи тренера. Спортсменів необхідно вчити боротися за свою мрію. Природа перемоги є результатом подолання людиною самого себе, своїх уподобань, свого небажання, своїх вагань. Таким чином, через самореалізацію в спорті формується здатність для подальиого щасливого життя.

Ключові слова: особистість, перемога, моральна підготовка, ідеал невтомності.

The hormone training of the athlete is relevant for the practical work of the trainer. The athletes must fight for their work. Nature can endure it as a result of the subordination of man to himself, of his own likeness, of his detachment, of his vas. Such a rank, through the self-revision of the sport, is formed a product for the lowly lowland life.

Key word: diversity, pathology, moral training, neuronostics.

Як відомо, особистість виступає продуктом соціально-історичного розвитку та суспільної діяльності людини. Зазначений продукт має власну свідомість та систему певних соціальних якостей, успішно виконує покладені на нього суспільством функції. Як і в інших видах людської діяльності, так і в спорті індивідуальність має важливе значення. Для того, щоб досягти успіху, необхідно правильно визначити індивідуальні особливості особистості спортсмена та зформувати на цій основі специфічний техніко-тактичний стиль його діяльності [3, с 1].

Знання особистості спортсмена $є$ вельми актуальним для роботи тренера. Це можна пояснити двома причинами: по-перше, індивідуальні особливості кожної окремо взятої особистості мають вирішальний вплив на результати спортивної діяльності; по-друге, спорт виступає одним із дієвих засобів виховання і формування особистості. Наявність зазначеного зв'язку висуває високі вимоги до підготовки тренера з питань знання психології особистості спортсмена. [4, с. 1]. 
У статті «Педагогічні принципи В. Г. Смілової як приклад синергії, традиції та інновації» я вже торкалась цієї проблеми і писала про те, що «спортсменів необхідно вчити боротися за свою мрію. Природа перемоги є результатом подолання людиною самого себе, своїх уподобань, свого небажання, своїх вагань. У будь-якій сфері життя, чи то праця, навчання чи спорт, лише з досягненням нової, не досяжної, внутрішньої межі прийде успіх. Подолай себе і тоді підкориться нова висота. Мрія про перемогу, про успіх у кожного своя. У плавця-новачка - це чекання миті, коли він переможе у своїй віковій групі. У майстра-сталевара - прагнення до рекордної плавки. У молодого дослідника - прагнення довести правильність своєї наукової концепції. І усіх їх поєднує одне - переборення» [1, с 87].

«Життєві уроки не можна порівнювати зі шкільними уроками. Спортивне життя викладає зовсім інші дисципліни. Уроки, що подає повсякденність не анонсуються, до них спеціально не підготуєшся. Але бути готовими до всіх випадків - цьому треба вчити спортсменів. Головне в шкільних предметах не окремі конкретні оцінки, а те чи опанував ти премудрість науки. Так і в житті - головне чи пішов спортсмену урок на користь, чи запам'ятав він його для застосування у майбутньому, чи він пройшов для нього марно, не знадобиться в подальшому, або просто не відповідає натурі. Спортивне життя на уроки не скупиться, залишаючи слід у душі та біографії» [1, с 88 - 89].

Потреба в подоланні перешкод задовольняється самим фактором подолання навіть у тому випадку, якщо кінцева мета залишається як i раніше далекою. Це особливо наочно проявляється в спортивній діяльності, коли спортсмени отримують задоволення не стільки від спортивних результатів, скільки від подолання труднощів.

Тренеру і спортсмену потрібно приділяти багато уваги моральній підготовці. Щоб підняти максимальний рівень мотивації спортсмена, треба його підтримувати, зберігаючи позитивну атмосферу, налаштовувати на поліпшення результатів. Відпрацьовувати техніку, тактику, витривалість, швидкість, силу й інші елементи, доводячи їх до автоматизма, підтримувати інтерес і стимул до важкої роботи.

Важливо не зациклюватися на своїх негативних емоціях під час тренування. Завжди необхідно думати над тим, що і як потрібно виправити, знайти пару технічних моментів, над якими треба попрацювати і сконцентруватися на них. 
Ідеал невтомності - вишколити себе так, щоб не відати втоми, мати завжди запас міцності. При подібній роботі в організмі неможливі шлаки і застої - все виявиться в постійному русі. Потрібно мріяти про невтомність і працювати з лютою захопленістю. Дратівливість це одна $з$ властивостей, що не гідні характеру спортсмена. Для того, щоб стати здоровим, сильним, щасливим і досягати вищих результатів - перш за все необхідно пристрасно бажати цього. Без цього почуття безглузді будь-які зусилля і надії. І цей настрій має переростати у віру, пронизувати і духовну, і фізичну суть особистості. Слабка воля - накладає обмеження на людину, можливості якої дивовижні!

Володіння знаннями, якщо вони не супроводжуються проявом і виразом у дії — марна і не розумна справа. Знання, як і здоров’я призначене для використання. Для того, щоб навчитися самореалізовувати себе як в спорті, так і в житті необхідно навчитися змінювати свій настрій або душевний стан, змінюючи свою вібрацію.

Таким чином, уміння долати перешкоди, мати максимальний рівень мотивації і пристрасне бажання щодо досягнення мети дозволяє спортсмену самореалізовувати себе в спорті та формує у нього здатність для подальшого щасливого життя.

\section{Список використаних джерел:}

1. Клімакова С. Педагогічні принципи В. Г. Смілової як приклад синергії, традиції та інновації. Традиційна культура в умовах глобалізації: синергія, традиції та інновації. Матеріали науково-практичної конференції (21-22 травня 2019 року). Харків : друкарня «Мадрид», 2019. С. 86-90.

2. Народна педагогіка. Світовий досвід / Кузьмінський А. Київ : ЗнанняПрес, 2003. 134 c.

3. Особистість спортсмена як суб'єкта спортивної діяльності. Режим доступу: https://studfiles.net/preview/5721472/page:18/

4. Психологія особистості та колективу в спорті. Режим доступу: http:// ua.textreferat.com/referat-10571-1.html 